\title{
Treatment of Acute Exacerbations in Leprosy with Indomethacin
}

\section{A PRELIMINARY REPORT}

\author{
A. C. PARIKH, M.B.B.s., D.v. \& D., F.c.P.s. \\ R. GANAPATI, в.SC., м.в.в.s. \\ Acworth Leprosy Hospital, Wadala, Bombay 31
}

Indomethacin, a new non-steroidal agent, has come into prominence in recent years as a useful anti-inflammatory, anti-pyretic and analgesic drug in the treatment of certain inflammatory joint diseases like rheumatoid arthritis, gout, ankylosing spondylitis, oesteoarthritis, etc. In these conditions this drug has been found to be as effective as other commonly used agents like corticosteroids, salicylates, phenylbutazone, etc. Unlike corticosteroids, indomethacin has no effect on pituitary or adrenal function, and when given concomitantly with corticosteroids, the dosage of the steroids can often be reduced. Silberman et al. (1965) found that indomethacin could be a useful adjunct in the symptomatic treatment of fever in Hodgkin's disease, lupus erythematosus, etc.

The foregoing experience prompted a clinical assessment of the anti-inflammatory and analgesic properties of indomethacin in the treatment of acute exacerbations of leprosy.

\section{MATERIAL AND METHODS}

Patients suffering from leprosy of all types with predominantly skin manifestation of the type of erythema nodosum leprosum (ENL) or tuberculoid lesions in reaction and those with polyneuritic involvement with marked pain and thickening of ulnar and peroneal nerves were selected for the study.

Thirty-one patients ( 28 males and 3 females) in the age group of 12 to 35 years were included in the trials. The type of leprosy was lepromatous in 19 patients, intermediate in 5 , and tuberculoid in 7 .

All the lepromatous and intermediate groups of patients were strongly positive bacterio- logically; and 19 out of 24 such patients had shown recurrence of lepra reaction on several occasions and had received calcium gluconate with antimonials or antimalarial drugs for each exacerbation. Five patients were experiencing reaction for the first time.

The tuberculoid patients were bacteriologically negative. Most of the patients with severe neuritis had been treated earlier with oral analgesic drugs with or without local ethyl chloride spray or perineural injections of hydrocortisone, or intradermal injections of 'hydnocreol' along the course of the nerve.

The dose of indomethacin $(25 \mathrm{mgm}$. per capsule) and duration of treatment varied in different patients depending upon the clinical response. In the majority of the patients a maximum of 100 to $150 \mathrm{mgm}$. in 3 or 4 divided doses was maintained daily after an initial period of treatment with $75 \mathrm{mgm}$. per day. After a varying period of treatment the dose was tapered off to $50 \mathrm{mgm}$. per day before stoppage.

The duration of treatment varied from 3 to 30 days except in one patient who was treated for a total period of 64 days intermittently to study the analgesic effect of the drug on neuritis. The majority of the patients received treatment for 7 to 12 days.

Most of the patients were admitted into the ward and a careful clinical assessment of the response of skin lesions during treatment was made. Record of their progress regarding regression of fever, neuralgia, arthralgia, etc., was made. Adverse symptoms, if any, attributable to the drug were recorded. 
TABLE I Showing response of Neuritis to Indomethacin

\begin{tabular}{lcccc}
\hline \multicolumn{1}{c}{ Type } & $\begin{array}{c}\text { No. of } \\
\text { Patients }\end{array}$ & $\begin{array}{c}\text { Marked } \\
\text { Response }\end{array}$ & $\begin{array}{c}\text { Moderate } \\
\text { Response }\end{array}$ & $\begin{array}{c}\text { No } \\
\text { Response }\end{array}$ \\
\hline Lepromatous & 10 & 5 & 3 & 2 \\
Intermediate & 3 & 3 & Nil & Nil \\
Tuberculoid & 6 & 4 & $2^{*}$ & Nil \\
\hline Total & 19 & 12 & 2 \\
\hline
\end{tabular}

* Two patients with ulnar nerve abscess.

TABLE 2 Showing response of skin lesions in Reaction to Indomethacin

\begin{tabular}{lccccc}
\hline \multicolumn{1}{c}{ Type } & $\begin{array}{c}\text { No. of } \\
\text { Patients }\end{array}$ & $\begin{array}{c}\text { Complete } \\
\text { Regression }\end{array}$ & $\begin{array}{c}\text { Partial } \\
\text { Regression }\end{array}$ & $\begin{array}{c}\text { No appreciable } \\
\text { Change }\end{array}$ & $\begin{array}{c}\text { Aggravation } \\
\text { of Lesions }\end{array}$ \\
\hline Lepromatous & 18 & 2 & 5 & 2 & 9 \\
Intermediate & 5 & 2 & 1 & Nil & Nil \\
Tuberculoid & 1 & Nil & Nil & 2 & 1 \\
\hline Total & 24 & 4 & 6 & 12 \\
\hline
\end{tabular}

\section{RESULTS AND DISCUSSION}

The tables show that the best results of the drug are obtained in patients with severe neuritis especially those belonging to the intermediate or tuberculoid types of leprosy.

The analgesic property of the drug was evident in the few cases of tuberculoid leprosy with unilateral ulnar neuritis resulting in marked limitation of movement of elbow joint. Often there was subjective sense of improvement due to relief from pain, and joint movement was restored.

However, the results obtained in the case of skin lesions in reaction were not encouraging. There was improvement in 10 patients but in 12 others the lesions were aggravated, the ENL lesions becoming more erythematous and sometimes undergoing necrosis. These findings are in line with the observations of García Fernandez (1965). In 2 patients no response was evident.

An objective assessment of the antipyretic effect of the drug was not possible as the majority of the patients in this trial did not have high fever. However, García Fernandez (1965) and Thiers et al. (1966) have reported that indomethacin is highly effective as an antipyretic in acute exacerbations of leprosy.

The side effects of indomethacin in the dosage employed in this study were minimal and, in general, drug tolerance was very satisfactory.
Three patients (one of whom had blurred vision) complained of giddiness 6 to 7 days after administration of the drug, and this symptom was relieved after withdrawal of the drug.

\section{SUMMARY}

The results of this preliminary clinical trial with indomethacin in acute exacerbations of leprosy indicate that the drug is an effective analgesic in producing symptomatic relief of neuralgia and arthralgia. The skin lesions, however, do not respond favourably and may, at times, be aggravated. The drug was well tolerated and there were very few side effects.

\section{ACKNOWLEDGEMENTS}

We are grateful to Dr. N. Figueredo, Special Officer, and Dr. N. D. Katdare, Superintendent, Acworth Leprosy Hospital, Wadala, Bombay 31, for their invaluable guidance during this investigation. We are also grateful to Dr. C. M. Anklesaria of Messrs. Merck Sharp \& Dohme of India for the free supply of Indomethacin.

\section{REFERENCES}

1. Silberman, H. R., MCGinN, J. C. and Kremer, w. B. Control of fever in Hodgkin's disease by indomethacin. J.A.M.A., 194, 597, 1965.

2. García Fernandez DE LARA. Treatment of leprosy reactions. Allergia, 13, 54, 1965.

3. thiers, h., rousset, J., CONDERT, M., Battesti, P. and THAN, L. H. Indomethacin in Febrile Episodes of Leprosy. Bull.Soc. Franc. Derm.Syph., 73, 347, 1966. 